\title{
MONITORING THE FLATHEADED BORER PTOSIMA UNDECIMMACULATA HERBST (COLEOPTERA: BUPRESTIDAE) IN ORANGE ORCHARDS IN EGYPT
}

\author{
HASHIM, S. M., R. M. ABD EL-MOATY and A. W. TADROS
}

Plant Protection Research Institute, Agric. Res. Center, MOA, Giza, Egypt.

(Manuscript received 22 February 2018)

\begin{abstract}
$\mathrm{P}$ opulation fluctuation of the economically important boring insect pest Ptosima undecimmaculata (Coleoptera: Buprestidae), attacking orange trees was monitored at Sharkia governorate during the two successive years 2015 and 2016. P. undecimmaculata prevailed from late March / early April to late October / early November. Three peaks were recorded during 2015 , during $2^{\text {nd }}$ half of June $(0.28$ beetle / tree $)$, the $1^{\text {st }}$ half of August ( 0.29 beetle / tree) and the $2^{\text {nd }}$ half of September ( 0.18 beetles / tree). Only two peaks were recorded in 2016, during the $1^{\text {st }}$ half of July ( 0.31 beetles / tree) and the $1^{\text {st }}$ half of September ( 0.36 beetles / tree). Summer months recorded the maximum flight (1.23 and 1.63 beetles), followed by spring ( 0.69 and 0.58 beetle), then autumn ( 0.09 and 0.12 beetle) /tree, and nearly stopped during winter ( 0.0 and 0.01 beetle) / tree in 2015 and 2016, respectively. The total numbers per year were 2.01 and 2.34 beetles/tree in 2015 and 2016, respectively. The respective means per tree / month were 0.17 and 0.20 beetles / tree / half month. It had two broods of beetles' activity and the beetles activity averaged 7.8 months. Effect of weather factors on the borer activity was mostly positively significant with day maximum, day minimum, and day mean temperatures but negatively and insignificantly with day mean relative humidity. Infestation was almost doubled during only one year, thus needed urgent integrated control.
\end{abstract}

\section{INTRODUCTION}

Citrus cultivation and production rank first in Egypt; since it is the most economic local popular and favorite fruit and highly exporting income.

The most widely spread citrus / varieties could be arranged descendingly in Egypt as follows: Valencia orange ( $C$. sinensis), Navel orange (Citrus sinensis), Balady orange ( $C$. sinensis), grapefruit ( $C$. paradisi), Mandarin ( $C$. reticulata), lime ( $C$. aurantifolia), Lemon ( $C$. limon), Sour orange ( $C$. aurantium) and Volkamer lemon ( $C$. volkameriana). Thus, harvesting period expanded from November to May to accommodate local and exporting markets.

Ptosima undecimmaculata stem borer (Coleoptera: Buprestidae) is widely distributed all-over the Mediterranean basin area on different fruit tree hosts such as mango, peach, plum, apricot, almond, etc. (Batt, 1999 and Hashim, 2009).

Frequent field observations all-over the governorates of Egypt indicated that in citrus orchards $P$. undecimmaculata is aserious boring pests causing cosiderabe damage. 
in Egypt Kinawy et al. (1992) and Tadros et al. (2006-a) monitored P. undecimmaculata population fluctuation in apricot orchards and Hashim and Ahmed (2011) in mango orchards. Larvae live and feed in a shallow tunnels under the bark of tree stem and main branches and cause girdling the wood, weakness, reducing the production, and finally their death.

The present ecological study is an attempt to contribute to such a gap in the knowledge on the the rate and degree of infestation, seasonal population fluctuation of the target pest population, the progress of infestation, the seasonal cycle, and the effect of the main weather factors. The broad objective of this investigation is to add new information that may help in planning successful and effective "Integrated Control Programs" for the management of tree borers in citrus orchards (Tadros et al., 2006-b).

\section{MATERIALS AND METHODS}

\section{Population fluctuation of $P$. undecimmaculata on citrus trees:}

\subsection{Seasonal abundance:}

One hundrered orange trees infested with $P$. undecimmaculata randomly distributed in a citrus orchard (about 5 feddans and more than 30 years old) located at Wadi El-Mollac, east Delta, Sharkia governorate were subjected to this investigation. Monitoring studies were carried out during two successive years extending from the beginning of January 2015 till the end of December 2016. No chemical treatments were applied in the selected area throughout population fluctuation studies. A paint brush marker was used to cancel the old exit holes.

From January $1^{\text {st }}, 2015$ until December 31, 2016, the new exit holes indicating emergence of $P$. undecimmaculata beetles were counted at half-monthly intervals on the $15^{\text {th }}$ and last day of every month. To avoid repeated counting new exit holes were immediately canceled with a spray paint marker after counting.

\subsection{Progress of infestation:}

Data of the seasonal abundance were accumulated from January $1^{\text {st }}, 2015$ until December 31, 2016 at half-monthly interval. The accumulated total number of beetles represented the number for one and two years together were calculated. To smooth the frequency distribution curve, data were smoothed according to the moving average formula:

\{(the actual number) + the previous number + the following number $\}$ / 3 , (Snedecor and Cochran 1990).

The present figures indicated the periods of the seasonal cycles of beetles activity and inactivity. Progress of infestation also indicated the rate of increasing in the borer infestation year after another. 


\section{Effect of weather factors on the activity of of $\boldsymbol{P}$. undecimmaculata on citrus trees:}

Four main weather factors, the day maximum temperature (DMxT), day minimum temperature (DMnT), day mean temperature (DMT) and day mean relative humidity (DMRH) were considered. Necessary weather data were obtained from the Central Laboratory of Climate and Meteorology, ARC, MOA, Giza.

Population data of $P$. undecimmaculata and the meteorological data, both at halfmonthly intervals, were presented. The relationship between the four weather factors and the target borer during the activity season was investigated for the two successive years extending from January 2015 until December 2016 in the citrus orchard.

To determine the direct effect of each weather factor on $P$. undecimmaculata activity, population counts were plotted against the corresponding weather data. The simple correlation coefficients " $r$ " for the relationship between each weather factor and the borer population was then worked out.

\section{RESULTS AND DISCUSSION}

\section{Population Fluctuation of $\boldsymbol{P}$. undecimmaculata on citrus trees:}

\subsection{Seasonal abundance:}

Tables ( 1 and 2 ) and Figure (1) showed that in citrus orchards beetles emergence of $P$. undecimmaculata prevailed during the period from the $2^{\text {nd }}$ half of March or $1^{\text {st }}$ half of April to the $2^{\text {nd }}$ half of October or $1^{\text {st }}$ half of November with two or three flight peaks during the two seasons of study.

In 2015 , beetles started to emerge during the $1^{\text {st }}$ half of April ( 0.02 beetle / tree) but during the $2^{\text {nd }}$ half of March ( 0.01 beetle / tree) in 2016.

Three peaks were recorded during 2015, the first peak was observed during $2^{\text {nd }}$ half of June 2015 ( 0.28 beetle / tree), a second peak was noticed during the $1^{\text {st }}$ half of August ( 0.29 beetle / tree) and a third peak during the $2^{\text {nd }}$ half of September ( 0.18 beetles / tree). During 2016, only two peaks were recorded during the $1^{\text {st }}$ half of July 2016 ( 0.31 beetles / tree) and the $1^{\text {st }}$ half of September ( 0.36 beetles / tree).

The last beetles flight was recorded during the $2^{\text {nd }}$ half of October, 2015 (0.03 beetle / tree), but continued to the $1^{\text {st }}$ half of November 2016 ( 0.02 beetle / tree) and ceased afterwards.

The maximum beetles' flight (1.23 and 1.63beetles / tree in 2015 and 2016, respectively) was in summer. Spring recorded the respective numbers 0.69 and 0.58 beetle / tree. Autumn showed the respective least beetle activity $(0 . \cdot 9$ and $0.1 \mathrm{r}$ 
beetle / tree). Beetles activity was almost stopped during winter $(0 . .0$ and 0.01 beetle / tree). Moreover, the total numbers of beetles emerged during the whole year were 2.01 and 2.34 beetles / tree in 2015 and 2016, respectively. The respective means per tree / month were 0.17 and 0.20 beetles / tree / half month.

Smoothed data in Table (1) and Figure (1) emphasized that $P$. undecimmaculata had only two broods of beetles' activity. The first one prevailed from the $1^{\text {st }}$ half of April to the $2^{\text {nd }}$ half of July, in the two seasons 2015 and 2016. The second brood was estimated from the $2^{\text {nd }}$ half of July to early November in both years of study. The two peaks of the broods were estimated during the $2^{\text {nd }}$ half of June and $1^{\text {st }}$ half of August, 2015. In 2016, the two peaks of the broods were estimated during the the $1^{\text {st }}$ half of July and the $1^{\text {st }}$ half of September, 2016.

\subsection{Progress of infestation:}

The cumulative numbers (seasonal cycle) of emerged beetles (Table, 1 and Figure, 1) was 7-8 months of beetles activity followed by 4-5 months of beetles inactivity. Infestation was almost doubled during only one year (from 2.01 beetles in 2015 to 4.35 beetles in 2016 / tree / year), thus, need urgent control of the pest year after another.

\subsection{Effect of temperature and relative humidity on beetles activity:}

Statistical analysis in Table (2) revealed that the fluctuation in beetles population was highly significant and positively correlated with the DMxT (" $r$ " from 0.7837 to 0.8534 ) and DMT ("r" from 0.7592 to 0.7998 ), but the DMnT ("r": from 0.6573 to 0.6961 ) in both 2015 and 2016. On the other hand, the effect of DMRH much varied on the fluctuation in the beetles' population showing insignificant and positively correlation (" $r$ ": 0.2368 ) in 2015 , but insignificant and negatively correlation ("r": - 0.0513) in 2016. 
Table 1. Mean number of $P$. undecimmaculata beetles in citrus orchards at Wadi ElMollac, Sharkia governorate during 2015 and 2016 seasons.

\begin{tabular}{|c|c|c|c|c|c|c|c|}
\hline \multirow{3}{*}{\multicolumn{2}{|c|}{$\begin{array}{c}\text { Date of } \\
\text { inspection }\end{array}$}} & \multicolumn{6}{|c|}{ Mean no. of beetles \tree } \\
\hline & & \multicolumn{3}{|c|}{2015 season } & \multicolumn{3}{|c|}{2016 season } \\
\hline & & \multirow{2}{*}{$\begin{array}{c}\text { Actual } \\
0.00\end{array}$} & \multirow{2}{*}{$\begin{array}{c}\begin{array}{c}\text { Smoothe } \\
\text { d }\end{array} \\
0.00 \\
\end{array}$} & \multirow{2}{*}{$\begin{array}{c}\text { Cumulative } \\
0.00 \\
\end{array}$} & \multirow{2}{*}{$\begin{array}{c}\text { Actual } \\
0.00 \\
\end{array}$} & \multirow{2}{*}{$\begin{array}{c}\text { Smoothed } \\
0.00\end{array}$} & \multirow{2}{*}{$\begin{array}{c}\text { Cumulative } \\
2.01 \\
\end{array}$} \\
\hline & $1-15$ & & & & & & \\
\hline Jail. & $16-31$ & 0.00 & 0.00 & 0.00 & 0.00 & 0.00 & 2.01 \\
\hline \multirow{2}{*}{ Feb. } & $1-15$ & 0.00 & 0.00 & 0.00 & 0.00 & 0.00 & 2.01 \\
\hline & $16-29$ & 0.00 & 0.00 & 0.00 & 0.00 & 0.00 & 2.01 \\
\hline \multirow{2}{*}{ Mar } & $1-15$ & 0.00 & 0.00 & 0.00 & 0.00 & 0.00 & 2.01 \\
\hline & $16-31$ & 0.0 & 0.01 & 0.00 & 0.01 & 0.01 & 2.02 \\
\hline \multicolumn{2}{|c|}{ Winter } & 0.0 & & & 0.01 & & \\
\hline \multirow{2}{*}{ Apr. } & $1-15$ & $0.0 r$ & 0.02 & 0.02 & 0.01 & 0.02 & 2.03 \\
\hline & $16-30$ & 0.04 & 0.05 & 0.06 & 0.03 & 0.04 & 2.06 \\
\hline \multirow{2}{*}{ May } & $1-15$ & 0.08 & 0.07 & 0.14 & 0.10 & 0.09 & 2.16 \\
\hline & $16-31$ & 0.11 & 0.12 & 0.25 & 0.12 & 0.12 & 2.28 \\
\hline \multirow{2}{*}{ Jun. } & $1-15$ & 0.16 & 0.18 & 0.41 & 0.13 & 0.14 & 2.41 \\
\hline & $16-31$ & 0.28 & 0.24 & 0.69 & 0.19 & 0.21 & 2.60 \\
\hline \multicolumn{2}{|c|}{ Spring } & 0.69 & & & 0.58 & & \\
\hline \multirow{2}{*}{ Jul. } & $1-15$ & 0.22 & 0.23 & 0.91 & 0.31 & 0.25 & 2.91 \\
\hline & $16-31$ & 0.19 & 0.22 & 1.10 & 0.20 & 0.24 & 3.11 \\
\hline \multirow{2}{*}{ Aug. } & $1-15$ & 0.29 & 0.25 & 1.39 & 0.23 & 0.24 & 3.34 \\
\hline & $16-31$ & 0.21 & 0.21 & 1.60 & 0.28 & 0.29 & 3.62 \\
\hline \multirow{2}{*}{ Sep. } & $1-15$ & 0.14 & 0.17 & 1.74 & 0.36 & 0.31 & 3.98 \\
\hline & $16-30$ & 0.18 & 0.14 & 1.92 & 0.25 & 0.23 & 4.23 \\
\hline \multicolumn{2}{|c|}{ Summer } & 1.23 & & & 1.63 & & \\
\hline \multirow{2}{*}{ Oct. } & $1-15$ & 0.07 & 0.08 & 1.98 & $0 . \cdot v$ & 0.11 & 4.30 \\
\hline & $16-31$ & $0.0 r$ & 0.03 & 2.01 & $0.0 r$ & 0.04 & 4.33 \\
\hline \multirow{2}{*}{ Nov. } & $1-15$ & 0.0 & 0.01 & 2.01 & 0.02 & 0.02 & 4.35 \\
\hline & $16-30$ & 0.00 & 0.00 & 2.01 & 0.00 & 0.01 & 4.35 \\
\hline \multirow{2}{*}{ Dec. } & $1-15$ & 0.00 & 0.00 & 2.01 & 0.00 & 0.00 & 4.35 \\
\hline & $16-31$ & 0.00 & 0.00 & 2.01 & 0.00 & 0.00 & 4.35 \\
\hline \multicolumn{2}{|c|}{ Autumn } & 0.99 & & & $0.1 r$ & & \\
\hline \multicolumn{2}{|c|}{ Grand Total } & 2.01 & & 2.01 & 2.34 & & 4.35 \\
\hline \multicolumn{2}{|c|}{$\begin{array}{c}\text { Mean/ tree/ } \\
\text { Month }\end{array}$} & 0.17 & & & 0.20 & & \\
\hline
\end{tabular}




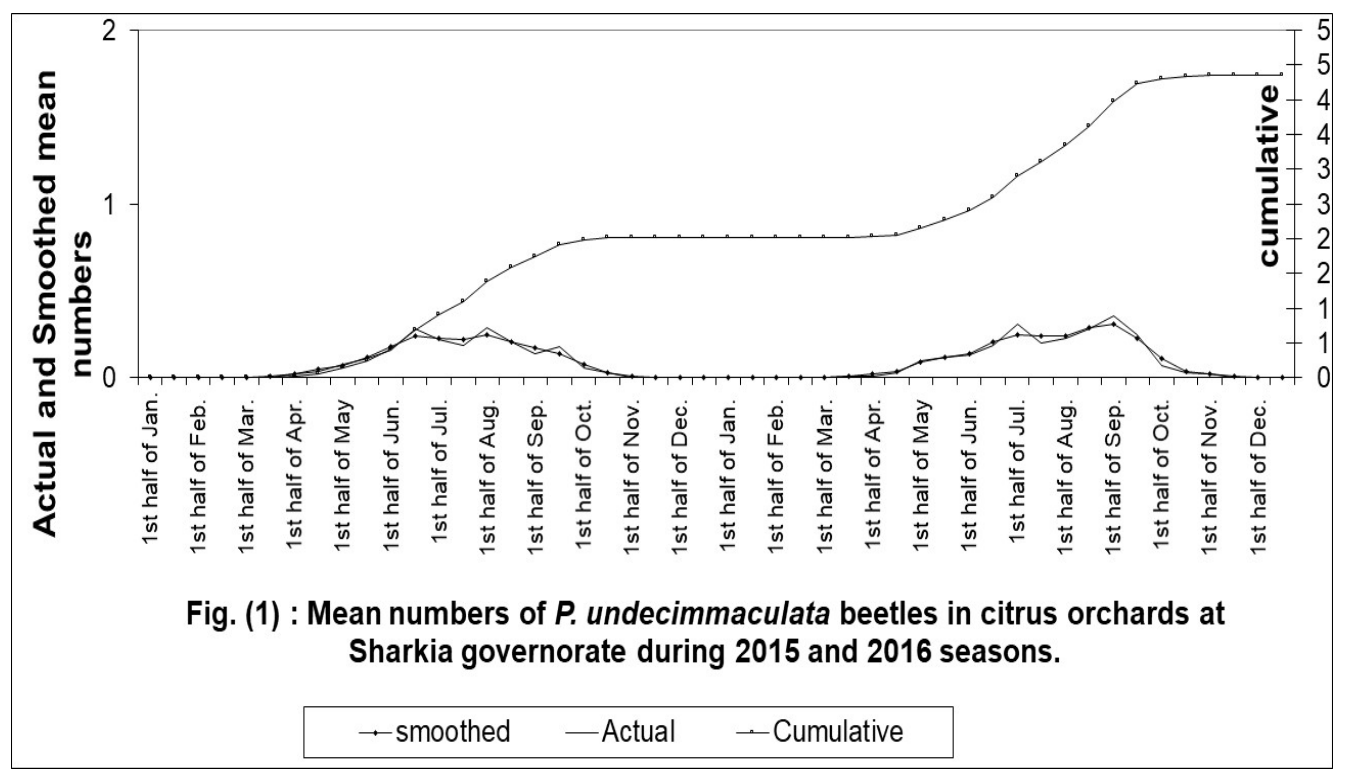

Table 2. Commencement, peak, last dates, and broods of $P$. undecimmaculata beetles in citrus orchards at Sharkia governorate, during 2015 and 2016 seasons, as well as simple correlation " $r$ " and Simple regression " $b$ " coefficients between the mean numbers of $P$. undecimmaculata beetles and the corresponding day maximum $(\mathrm{DMxT})$, day mean (DMT), day minimum temperatures (DMnT) and day mean relative humidity (DMRH) during 2015 and 2016.

\begin{tabular}{|c|c|c|}
\hline \multirow{2}{*}{ Statement } & \multicolumn{2}{|c|}{ Year } \\
\hline & 2015 & 2016 \\
\hline Flight Commencement & $2^{\text {nd }}$ week of March & $1^{\text {st }}$ week of Apr. \\
\hline $\begin{array}{r}\text { Peaks: } 1^{\text {st }} \text { peak } \\
2^{\text {nd }} \text { peak } \\
3^{\text {rd }} \text { peak }\end{array}$ & $\begin{array}{c}2^{\text {nd }} \text { half of June } \\
1^{\text {st }} \text { half of August } \\
2^{\text {nd }} \text { half of September }\end{array}$ & $\begin{array}{c}1^{\text {st }} \text { half of July } \\
1^{\text {st }} \text { half of September }\end{array}$ \\
\hline Last flight & $2^{\text {nd }}$ half of October & $1^{\text {st }}$ half of November \\
\hline Broods: $\mathbf{1}^{\text {st }}$ brood & \multicolumn{2}{|c|}{ From $1^{\text {st }}$ half of April to $2^{\text {nd }}$ half of July } \\
\hline $2^{\text {nd }}$ brood & \multicolumn{2}{|c|}{ From $2^{\text {nd }}$ half of July to $1^{\text {st }}$ half November } \\
\hline $\begin{array}{c}\text { Peaks of the broods } \\
\mathbf{1}^{\text {st }} \text { brood peak } \\
\mathbf{2}^{\text {nd }} \text { brood peak }\end{array}$ & $\begin{array}{l}2^{\text {nd }} \text { half of June } \\
1^{\text {st }} \text { half of August }\end{array}$ & $\begin{array}{c}1^{\text {st }} \text { half of July } \\
1^{\text {st }} \text { half of September }\end{array}$ \\
\hline $\begin{array}{l}\text { Summer months } \\
\text { Spring months } \\
\text { Autumn months } \\
\text { Winter months }\end{array}$ & $\begin{array}{l}1.23 \text { beetles / tree } \\
0.69 \text { beetle / tree } \\
0 . .9 \text { beetle / tree } \\
0 . .0 \text { beetle / tree }\end{array}$ & $\begin{array}{l}1.63 \text { beetles / tree } \\
0.58 \text { beetle / tree } \\
0 . .9 \text { beetle / tree } \\
0.01 \text { beetle / tree }\end{array}$ \\
\hline $\begin{array}{l}\text { Total numbers / year } \\
\text { Mean nos. / month }\end{array}$ & $\begin{array}{l}2.01 \text { beetles/tree } \\
0.17 \text { beetles / tree }\end{array}$ & $\begin{array}{l}2.34 \text { beetles/tree } \\
0.20 \text { beetles / tree }\end{array}$ \\
\hline $\begin{array}{c}\text { Simple correlation "r" } \\
\text { coefficients } \\
\text { DMxT } \\
\text { DMT } \\
\text { DMnT } \\
\text { DMRH }\end{array}$ & $\begin{array}{c}0.7837 * * \\
0.7592 * * \\
0.6573 * * \\
0.2368\end{array}$ & $\begin{array}{l}0.8534 * * \\
0.7998 * * \\
0.6961 * * \\
-0.0513\end{array}$ \\
\hline $\begin{array}{c}\text { Simple regression "b" } \\
\text { DMxT } \\
\text { DMT } \\
\text { DMnT } \\
\text { DMRH }\end{array}$ & $\begin{array}{c}46.02 * * \\
44.65 * * \\
43.53 * * \\
8.34\end{array}$ & $\begin{array}{c}45.64 * * \\
42.38 * * \\
40.97 * * \\
-4.05\end{array}$ \\
\hline
\end{tabular}

**: Significant at 0.01 levels (Highly significant)

*: Significant at 0.05 levels (Significant) 


\section{Discussion and conclusion:}

Monitoring studies (especially the sesonal fluctuation of insect borer population, progress of infestation, seasonal cycle, and effect of the main weather factors on the target pests) are essential in planning successful and effective "Integrated Control Programs" for the management of boring insect pests (Tadros et al, 2006-b).

In citrus orchards $P$. undecimmaculata beetles activity started from late March / early April and was stopped by the end of October / early November. Summer and spring are the seasons of avtivity. The activity season extended for 7 to 8 months. There were 2 to 3 flight peaks for the borer activity. Infestation was almost doubled during only one year, thus needed urgent integrated control. Larvae however, are existed all the year round inside the wood tunnels, but larval duration are prolonged in winter.

Survey studies of Hashim (2009) indicated that $P$. undecimmaculata is dominanting and economically important borer in mango orchards These results somewhat in agreement with Batt (1999) who surveyed $P$. undecimmaculata in apricot orchards from very early of March until the very late of September, with three population peaks. Kinawy et al. (1992) stated that $P$. undecimmaculata beetles activity in apricot orchards highly affected with temperature but not with relative humidity. Also, similar results were obtained by Abd El-latif (1995) in apricot orchards in Fayoum governorate. Emergency collabsed 6.5 months, from April / May until October, and has two flight peaks. Summer and spring months recorded the maximum beetle activity. However, literature from abroad concerning $P$. undecimmaculata is lacking. Hashim and Ahmed (2011) also found that $P$. undecimmaculata beetles activity in mango orchards started to emerge from $1^{\text {st }}$ half of April or $2^{\text {nd }}$ half of march during 2010 and 2011 seasons respectively and has one flight peak during the $1^{\text {st }}$ half of May or the $2^{\text {nd }}$ half of April during 2010 and 2011 seasons, respectively.

\section{REFERENCES}

1. Abd El-latif, N. A. 1995. Studies on some insect pests of apricot trees and associated natural enemies in Fayoum governorate. M. Sc. Thesis, Fac. of Agric., Fayoum, Cairo, Egypt, 176 pp.

2. Batt, A. M. 1999. Survey of borers attacking deciduous fruit trees in Egypt with reference to certain biological and ecological studies. Egyptian Journal of Agricultural Research, 77 (3): 1081-1102. 
3. Hashim, S. M. 2009. Ecological and Control Studies on Mango Tree Borers and Their Natural Enemies in Egypt. Ph D Thesis, Faculty of Science, Cairo University.

4. Hashim, S. M. and Ahmed, H.M. A. (2011): Population fluctuation of the metalic Beetle Ptosima undecimmaculata (HERBEST) (Coleoptera: Buprestidae) in Mango Orchards. Bull.Ent.Soc. Egypt, 88, 2011(169 - 177).

5. Kinawy, M. M.; F. F. Abd-Allah and A. W. Tadros. 1992. Seasonal abundance of the plum woodborer, Ptosima undecimmaculata Herbst (Coleoptera: Buprestidae) on apricot in Egypt. Communications in Science and Development Research, Alexandria, Egypt, 40 (496): 231-242.

6. Tadros, A.W., A. M. Abdel-Rahman and I. A. Abdel-Hamid (2006-a): Stone Fruit Pests: (5) Monitoring the major apricot tree borers (Ptosima undecimmaculata, Chlorophorus varius, Macrotoma palmate and Scolytus amygdali (Col.: Scolytidae) in Egypt. Egypt. J. Agric. Res., Egypt, 84 (6): 1789-1809.

7. Tadros, A.W., A. M. Abdel-Rahman and I. A. Abdel-Hamid (2006-b): Stone Fruit Pests: (6) Alternative means of control of Ptosima undecimmaculata by horticultural, mechanical, microbiological and local chemical treatments in apricot orchards in Egypt. Egypt. J. Agric. Res., Egypt, Feb 19th, 2006.

8. Snedecor, W and A. Cochran. 1990. Statistical Methods. The Iowa State Univ. press, Ames, Iowa, USA. 


\section{تتبع تعداد حفار ساق البرقوق ذو الراس المفلطح}

\section{Ptosima undecimmaculata}

\section{في حدائق البرتقال في مصر (Coleoptera: Buprestidae)}

صلاح محروس هاشم ، راضي محمدي عبد المطي و انطون ولسن تادرس

معهد بحوث وقاية النباتات- مركز البحوث الزراعية- وزارة الزراعة- الدقي - الجيزة- مصر.

تم تتبع تعداد حفار ساق البرقوق ذو الرأس المفلطح Ptosima undecimmaculata في

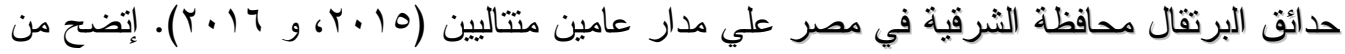

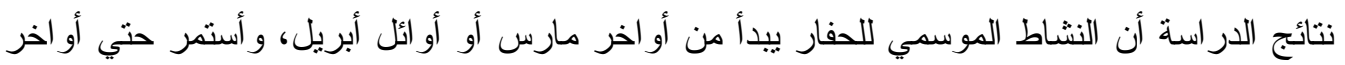

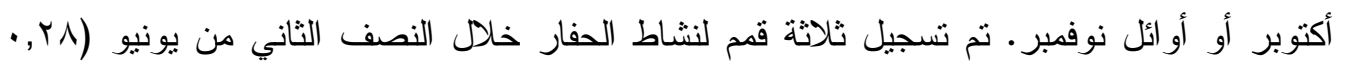

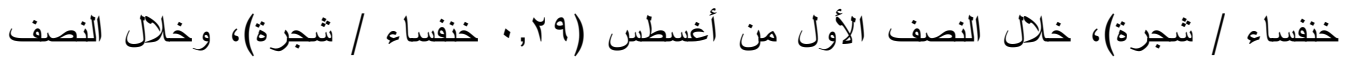

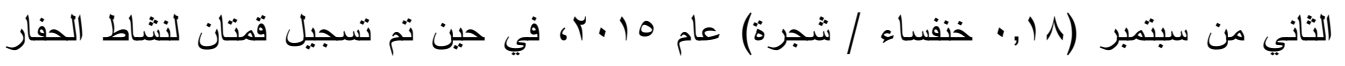

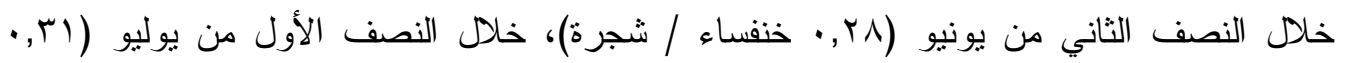

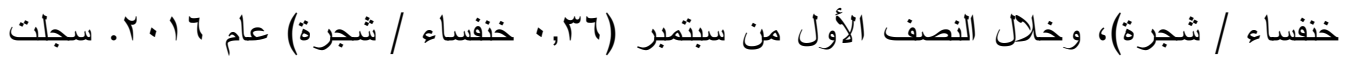

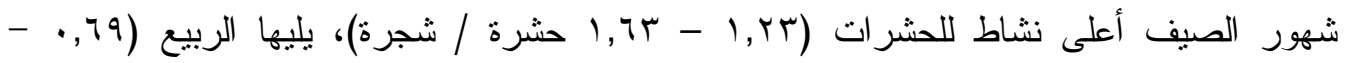

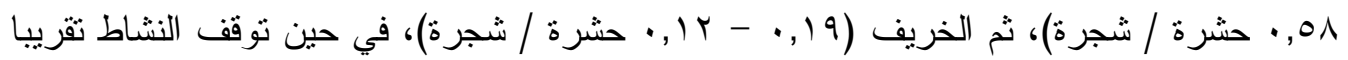

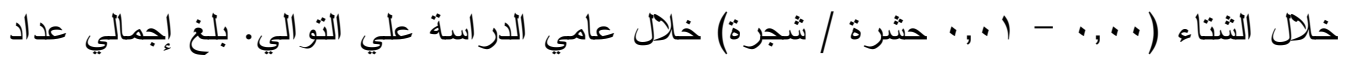

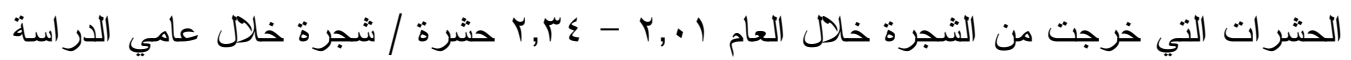

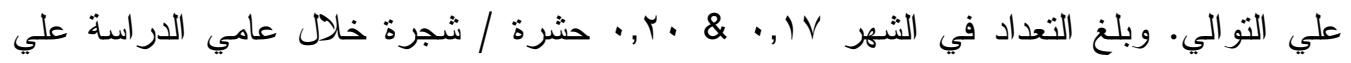
التو الي. وللحفار حضنتان من النشاط خلال العام. وهناك دورة من نشاط الحشرات لمدة ل

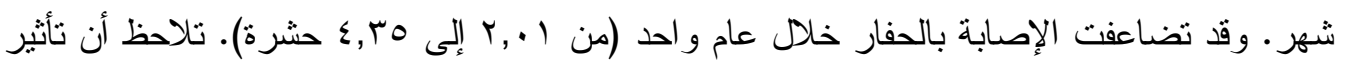

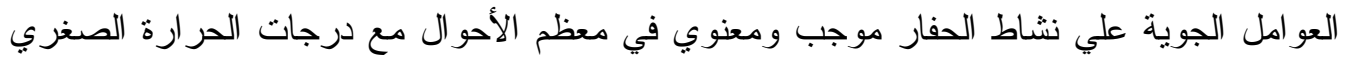
و المتوسطة و العظمي، ولكنها سالبة أو موجبة ولكن غير معنوية مع متوسط الرطوبة فئ النسبية. 
